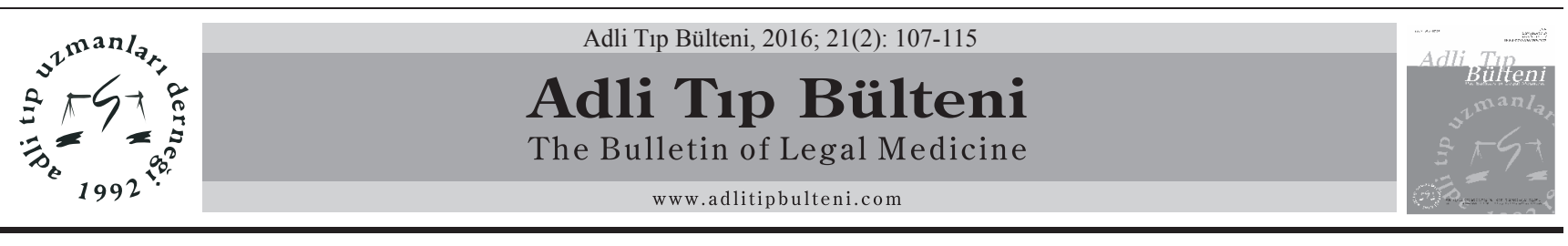

\title{
Cesedin Ayrışma Durumuna Göre Birikmiş Gün Sıcaklıkları ile Postmortem İnterval Tahmini
}

\section{Postmortem Interval Estimation Using Accumulated Degree Days According to the Body's Decomposition Stage}

\author{
Özgür Bulut ${ }^{1}$, Semih Bol'2, Ramazan Akçan ${ }^{3}$ \\ ${ }^{1}$ Hitit Üniversitesi, Fen-Edebiyat Fakültesi, Antropoloji Bölümü, Çorum \\ ${ }^{2}$ Kriminal Polis Laboratuvarı Müdürlüğ̈̈, Adli Antropoloji Birimi, Ankara \\ ${ }^{3}$ Hacettepe Üniversitesi, Tıp Fakültesi, Adli Tıp Anabilim Dalı, Ankara
}

\begin{abstract}
Özet
Postmortem interval dünyada modern adli bilim uygulamalarında çok önemli yere sahip araştırma konularından birisi olarak karşımıza çıkmaktadır. Postmortem intervalin belirlenmesinde morfolojik, biyokimyasal, adli patolojik, flowsitometrik, mikrobiyolojik, entomolojik, antropolojik, spektroskopik ve ana postmortem değişimler gibi çok sayıda yöntem kullanılmasına karşın tek bir test ya da yöntem ile kesinlik içeren sonuçların verilebilmesi mümkün görülmediğinden kullanılan parametreleri etkileyen birçok fiziksel, kimyasal ve biyolojik süreç bulunmaktadır. $\mathrm{Bu}$ nedenle, postmortem interval hesaplanmasinda mümkün olduğunca yeni yönteme ve kullanılagelen yöntemlerin geliştirilmesine ihtiyaç duyulmaktadır. Bu noktada, postmortem interval tahmininde kullanılan tafonomik yöntemlerin de geliştirilmesi, uygulamalı çalışmalarla bölgesel faktörler ve iklim etkisinin ortaya konması gerekmektedir. Özellikle, postmortem sürece etki eden bölgesel faktörlerin belirlenmesi ile ölüm sonrası geçen sürenin tahmininde daha kesin sonuçlara ulaşılabileceği kanaatindeyiz. Bu makalede, cesedin ayrışma durumuna göre birikmiş gün sıcaklıkları kullanılarak postmortem interval tahmini ile ilgili güncel bilimsel verilerin değerlendirilmesi amaçlanmıştır.
\end{abstract}

Anahtar Kelimeler: Adli Tafonomi; Postmortem İnterval; Adli Antropoloji.

\section{Giriş}

Postmortem interval (PMİ) tayini bir adli ölüm vakasinda sorulan ve cevabı aranan temel ve önemli sorulardan birisidir. PMİ'nin tespit edilmesi, adli vakanın aydınlatılmasındaki en önemli unsurlar arasında yer almaktadır. Bu nedenle, PMİ modern adli bilim uygulamalarında çok önemli yere sahip araştırma konularından biri olarak

Sorumlu Yazar: Doç.Dr. Özgür BULUT

Hitit Üniversitesi, Fen-Edebiyat Fakültesi,

Antropoloji Bölümü, 19040, Çorum

E-posta: ozgur.bulut@gmail.com

Geliş: 07.01.2016 Düzeltme: 29.01.2016 Kabul: 16.02.2016

\begin{abstract}
Postmortem interval arises as one of the most important research topics in worldwide modern forensic science applications. In spite of utilizing morphological, biochemical, flow-cytometric, microbiological, entomological, anthropological, spectroscopic and main postmortem changes in postmortem interval estimation, it does not seem possible to get certain results by only one test or method, since there are many physical, chemical and biological processes affecting the parameters. Therefore, postmortem interval estimation needs development of previous methods and implementation of novel methods. In this regard, taphonomic methods need to be improved in postmortem interval estimation and regional factors and climate impact need to be determined by experimental studies. In particular, we are of the opinion that that more accurate estimation of postmortem interval will be achieved by determining regional factor involving postmortem period. This paper aims to evaluate the current scientific data related to the estimation of postmortem interval using accumulated degree days in respect of decomposition stages.
\end{abstract}

Keywords: Forensic Taphonomy; Postmortem Interval; Forensic Anthropology.

karşımıza çıkmaktadır.

Ölümden hemen sonra cesette fiziksel, kimyasal ve biyolojik değişiklikler başlamakta ve tüm dokular yıkılana kadar ayrışma devam etmektedir. Bu değişimlerin cesette neden olduğu değişiklikler esas alınarak PMİ tahmini yapılmaktadır. PMİ tahmininde kullanılan yöntemlerin başlıcaları; ölü lekeleri (1-5), ölü katılığı $(6,7)$, ölü soğuması (2,8-10), vücut sıvılarının postmortem biyokimyasal incelemeleri $(2,3,6,7,11-16)$ mide boşalması $(1,2,7)$, elektrofizyolojik çalışmalar $(17,18)$, flow-sitometrik çalışmalar $(19,20)$, mikrobiyolojik çalışmalar (21-23) ve entomolojik çalışmalardır (24-34). Bunun dışında ülke- 
mizde yapılan, iskelet kas dokusundaki postmortem element seviyesi tespiti (35), beyaz kan hücrelerindeki değişim (36) ve böbrek üstü bezinin morfometrik değişikliklerinin tespiti (37) ile de postmortem interval konusunda yapılmış çalışmalar bulunmaktadır. Entomolojik incelemeler hariç tüm yöntemler ölümden sonraki çok erken evrede kullanılabilmektedir. Görüldüğü gibi literatürde PMİ belirlenmesinde birçok yöntem geliştirilmiş olmasına ve kullanılmasına karşın sürece müdahil olan fiziksel, kimyasal ve biyolojik faktörler nedeniyle tek bir test ya da yöntem kullanılarak kesinlik içeren sonuçlar verilmesi mümkün olmamaktadır. Diğer yandan, özellikle ayrışma süreci belirginleşmiş cesetlerde PMİ tahmininde bu yöntemlerin anlamı bulunmamaktadır. Bu noktada, yukarıda sözü edilen yöntemlerin aksine, cesetteki postmortem değişimleri ve bu değişimlerin zaman-interferan faktörlerle ilişkisini ortaya koyan önemli bilimsel metodoloji olan tafonomi devreye girmektedir. Ayrışma sürecinin belirginleşmesi ile birlikte PMİ tahmininde kullanılan tafonomik yöntemlerin de geliştirilmesi ve uygulamalı çalışmalarla bölgesel faktörler ile iklim etkisinin ortaya konması gerekmektedir. Bu yazımızda, cesedin ayrışma durumuna göre birikmiş gün sıcaklıkları ile postmortem interval tahmini arasındaki ilişkinin değerlendirilmesi amaçlanmıştır.

PMİ tahmini yapmak için dış faktörleri ve bu faktörlerin etki derecelerine hâkim olmak gerekmektedir. En başta mevsim, sıcaklık, nem, zoo-coğrafik bölge, arazi tipi, toprak tipi olmak üzere, cesedin lokasyonu, yani güneşli-gölgeli, açık-kapalı mekânda olma durumu, bölgenin bitki durumu, böcekler arasındaki rekabet ve yiyecek durumu gibi faktörlerin bilinmesi gerekmektedir (38). PMI tahmininde ayrışma sürecine etki eden bölgesel iklim farklılıkları, ülkeden ülkeye hatta aynı ülkede bölgeden bölgeye ve aynı bölgede bile zaman içerisinde değişiklik göstermektedir. Bu değişkenleri doğru anlamak ve birbirleri ile olan ilişkilerini ortaya koyabilmek için adli tafonomiye ihtiyaç duyulmaktadır.

Adli tafonomi, ölümden sonraki olayları ve etkenleri sırasıyla canlandırıp sonrasında PMİ tahmini için toplanan verileri analiz etme imkanı sunmaktadır (39). Son yaklaşımlar ayrışma durumunun ölçülmesi ve skorlanmas1 ile yapılan posmortem interval tahmininin daha etkili ve güvenilir olduğunu göstermiştir $(40,41)$. Bu verilerin "Birikmiş Gün Sıcaklıkları -Accumulated Degree Days(ADD)" ile birlikte kullanılmasıyla PMİ konusunda daha güvenilir ve bilimsel sonuçlara ulaşılmaktadır $(41,42)$. PMİ'nin kayıp şahısların belirlenmesi ve cinayet vakasındaki muhtemel şüpheli ve/veya şüphelilerin ayırt edilmesinde önemi büyüktür. Örneğin; olay yerindeki cesede ait PMİ'nin ortalama 5 aylık olduğunun belirlenmesi duru- munda çok daha uzun zamandan beri kayıp olan bireylere bakılmasına gerek kalmamaktadır.

\section{Adli Tafonomi}

Tafonomi kabaca "ölüm hukuku - mezar yasaları" anlamına gelir. Bir Rus bilim adamı olan Efremov 1940 y1lında tafonomi terimini kullanmıştır (43). Yakın zamana kadar tafonomi; omurgalı paleontolojisi, tarih arkeozoolojisi ve arkeoloji için de ağırlıklı olarak kullanılan bir terim olmuştur.

Ölümden sonra geçen süreci doğru anlamak, yorumlamak ve yeniden inşa etmek için ise tafonomi bilimine ihtiyaç duyulmaktadır. Adli tafonomi ise ilk kez 1989 y1lında Adli Bilimler Dergisi'nde (Journal of Forensic Sciences) bir "anahtar kelime" olarak ortaya çıkmıştır (44). Adli tafonominin adli antropoloji alanında önemli bir gelişme gösterdiği Dirkmaat ve ark.'1 (45) tarafindan tespit edilmiştir. Bahse konu çalışmada tafonominin tarihi ve adli antropoloji üzerindeki önemli etkisi anlatılmaktadır. Başka bir çalışmada ise adli tafonominin adli vaka bağlamındaki eşsiz rolünden, adli tafonominin genel ilke ve yöntemlerinden bahsedilmiştir (46).

PMİ tahminine yönelik iki önemli çalışmadan birisi Vass ve ark. (47) tarafından yapılan çalışmadır. İnsan kadavralarının altındaki toprakta bulunan uçucu yağ asitlerine dayalı deneysel bir çalışmadır. Bu çalışma, vücut yağının toprak içerisindeki oranının ölçülmesine dayanmaktadır. ADD kavramı ilk kez tanıtılmaktadır. Postmortem interval hesaplanmasinda ADD ve vücut kitlesi kullanılmaktadır (47).

Adli tafonomi alanındaki diğer önemli bir çalışma ise Megyesi ve ark. (41) tarafından yapılan çalışmadır. $\mathrm{Bu}$ çalışmada nicel ve nitel veriler kullanılmış ve insan kadavralarına dayalı retrospektif bir vaka çalışması yürütülerek ayrışma aşamaları ve evreleri için standart bir skorlama sistemi geliştirilmiştir. Vücutta üç bölgedeki (baş-boyun, gövde ve kol-bacak) nitel veriyi 'toplam vücut skoru -total body score-' (TBS) ile nicel veriye çevirmiştir. PMI hesaplanmasına ADD ile birlikte TBS kullanılmıştır. ADD değeri kullanılarak oldukça doğru PMI tahminlerine ulaşılmıştır

Çeşitli faktörler, oranlar ve bunların sıralaması ayrışma durumunu etkileyebilmektedir $(40,48,49)$. Bu anomaliler nitel ve nicel dekompozisyon çalışmalarını doğrudan etkilemektedir. PMİ tahmini nadiren bir değişken üzerinden ve diğeri izole edilerek yapılabilmektedir (48).

Coğrafi alan, büyük ölçüde dekompozisyon aşamalarının sayısını ve her aşamanın ulaşması gereken süreyi etkileyecektir. Örneğin; ortamdaki sıcaklık ve neme bağlı olarak mumyalaşma (mummification) veya sabunlaşma (adipocere) çürümeye dâhil olacaktır $(41,50)$. Smith'e 
(38) göre ise en başta mevsim, sicaklık, nem, zoo-coğrafik bölge, arazi tipi, toprak tipi olmak üzere, cesedin güneşli-gölgeli, açık-kapalı yerde olma durumu, bitki durumu, böcekler arasındaki rekabet ve yiyecek durumu gibi faktörlerin bilinmesi gerekmektedir.

\section{Cesedin Ayrışma Durumuna Göre Birikmiş Gün Sıcaklıkları ile Postmortem Interval Tayini}

Erken dönem postmortem süreç çok az değişkenden etkilendiği için tahminler daha kısa zaman aralığında (saat/ gün) yapılır. Geç dönem postmortem sürece doğru ise sürenin de uzamasına bağlı olarak etki eden faktörlerin arttığı görülmektedir. Kullanılabilecek birincil yöntemin yumuşak dokunun ayrışması ve iskelet dokusundaki değişiklikler olduğundan dolayı tahmin sürelerinin arttığı (hafta/ay) görülmektedir $(51,52)$. Çürümüş bir ceset PMI tayini açısından önemli bilgiler verebilmektedir. Ölüm sonrası aralığın tahmini için ölüm sırasındaki çevrenin incelenmesi ve yumuşak dokunun iskeletleşme oranının tespiti gerekmektedir (45). Cesedin bulunduğu bölgenin habitatı, bitki durumu, toprak tipi ve meteorolojik durumu da önemli faktörlerdendir ve cesede gelen böceklerin türüne ve çürümesine etki etmektedir (53). Bunun yanında cesedin gömülmesi, suya atılması, herhangi bir objeye sarılması, açı veya kapalı bir ortamda bulunması gibi çeşitli faktörler cesedin dekompozisyonunu doğrudan etkilemektedir (26,38,54-56).

Mann ve ark. (48) tarafindan yapılan çalışmada, dekompozisyonu etkileyen faktörleri sırasıyla; sıcaklık, böcek ve defin/derinlik olarak belirtmiştir. Sonrasında etkileyen faktörler; etobur/kemirgenler, travma, nem/ kuraklık, yağış, vücut büyüklüğü/ağırlığı, mumyalaşma, giyim, toprak yüzeyinde olma, topraktaki PH'tır. Smith'e (38) göre ise en başta mevsim, sıcaklık, nem, zoo-coğrafik bölge, arazi tipi, toprak tipi olmak üzere, cesedin güneşligölgeli, açık-kapalı yerde olma durumu, bitki durumu, böcekler arasındaki rekabet ve yiyecek durumu gibi faktörlerin bilinmesi gerekmektedir. Sayısız değişken olmasına rağmen yumuşak dokunun ayrışmasını birinci derecede etkileyen faktör sicaklıktır $(41,57)$. Dekompozisyon sürecinde yumuşak dokunun ayrışması için bakteri çoğalmas1 ve böcek gelişimine, bunların olması için de sıcaklığa ihtiyaç vardır (57). Sicaklık ve ayrışma oranı Van’t Hoff Kanunu (10 kanunu veya Q10 kanunu) ile bağlantılıdır. $\mathrm{Bu}$ kanuna göre her $10^{\circ} \mathrm{C}$ sicaklık yükselmesinde kimyasal reaksiyonların hızı iki katı ya da daha fazla olmaktadır (58). Bundan dolayı ölüm sonrası geçen sürenin tahmininde birincil olarak sıcaklık ele alınmalıdır $(41,58)$.

Adli tıp uzmanları ve adli antropologlar ölümden sonraki dekompozisyon sürecindeki cesedin ayrışma safhası$\mathrm{n} 1$ inceleyerek ve skorlayarak postmortem aralık hakkında tahminde bulunabilirler $(39,40,60,61)$. Dekompozisyon sürecinde etken olan değişkenleri doğru anlamak ve yorumlamak bizi doğru PMİ tahminine götürür. Son yıllarda iki anahtar kavram "Birikmiş Gün Sıcaklıkları - Accumulated Degree Days (ADD)" ve "Toplam Vücut Skoru Total Body Score (TBS)" ölümden sonra geçen zamanın belirlenmesini teorik olarak daha basit hale getirmiştir (62). ADD kavramını kullanarak daha doğru bir ölüm sonrası zaman bulmak mümkündür $(41,42)$. Gün sayısının bulunması için sıcaklığın ortaya çıkartılması gerekir. Öncelikle başlama noktası gündür. Bulunma anından itibaren geriye doğru sıcaklıklar toplanarak gün sayısı çıkarılır.

ADD kullanımı araştırmacılara farklı coğrafi bölge ve ortamda sıcaklığa bağlı ayrışma hızını karşılaştırma imkânı verir (62). Coğrafi ve iklimsel olarak sıcaklıklar farklı olduğundan, sıcaklığı zaman ile birleştirip tek bilinmeyen haline getirmek için ADD kullanılır. Böylece iki bilinmeyen olan sıcaklık ve zaman birleştirilerek tek bilinmeyenli standardize edilir. Sicaklık ve zaman bazlı çalışmanın nedeni, ayrışma sürecini etkileyen çok fazla değişken olması ve bunları teke düşürerek daha detaylı ve bölgesel olarak incelemektir.

ADD ile TBS birlikte kullanılır. Megyesi ve ark. (41) tarafindan yapılan çalışmada, bir cismin ayrışma durumunu açıklamak için TBS olarak ifade edilen "toplam vücut skoru” kullanılmıştır. Dekompozisyonu tanımlamak için nicel olarak rakamlar verilmiş ve dekompozisyon aşamalara ayrılarak numaralandırılmıştır (Tablo 1). Geliştirilen bu metotta vücut üç bölüme ayrılmış (1: gövde, 2: baş ve boyun, 3: kol ve bacak) ve bu üç bölüm ayrışma durumuna göre skorlanmıştır (Şekil 1). Skorlama neticesinde elde edilen TBS ile Megyesi tarafindan geliştirilen formülle ADD'ye ulaşılır. ADD bulunmasından sonra ortalama sıcaklık verilerinin kullanılmasıyla PMİ elde edilir.

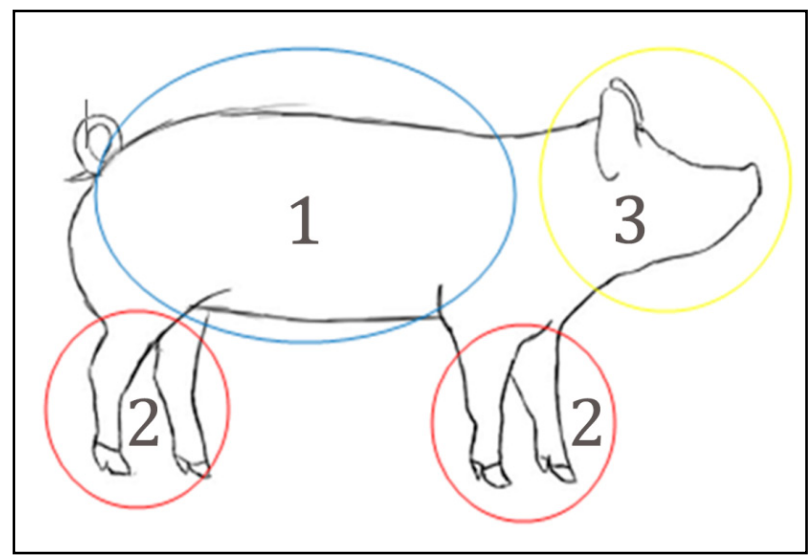

Şekil 1. Toplam vücut skoru hesaplamak için kullanılan üç anatomik bölge 1: Gövde, 2: Kol ve bacak , 3: Baş ve boyun 
Genel olarak dekompozisyon sürecinde ayrışmaya bağlı olarak TBS skorlarında görülen değişimler; 8-13 TBS aralığında ağız ve burun gibi yüzdeki doğal açıklıklardan dekompozisyon sıvılarının çıkışı, 14-26 TBS aralığında kafanın yarıdan az alanında kemik gözükmesi, 11-19 TBS aralığında karın şişmesi, 20-35 TBS aralığında gögüs bölgesinde kemik gözükmesi, 21-35 TBS aralığında ise kol ve bacaklarda kemik gözükmesi izlenmektedir (41).
ADD'yi kısaca tanımlamak gerekirse; dekompozisyonla sıcaklığı ilişkilendirmek için ardışık gün sıcaklıklarının ${ }^{\circ} \mathrm{C}$ olarak toplanmasıdır $(41,47,63)$. ADD'yi bulmak için günlük sıcaklık ortalaması alınır ve toplanır (48).

ADD kavramı zaman ve sıcaklık değişkenlerinin ölçüsü olarak, PMİ tahmini için ADD ve vücut kütlesi birleştirilmiştir. ADD ile bir cesedin iskeletleşmesi için toplamda birikmiş bir sıcaklık gereklidir. Ortalama olarak 68 kg ağırlığında bir insanın iskeletleşmesi 1285 ADD'dir

Tablo 1. Dekompozisyon aşamaları*

\begin{tabular}{|c|c|c|c|c|c|}
\hline Așama & Skor & No & Baş-boyun & Gövde & Kol-bacak \\
\hline $\begin{array}{l}\text { Erken } \\
\text { ayrışma } \\
\text { I. Dönem }\end{array}$ & $1 P$ & 1 & Renk değişikliği yok & Renk değişikliği yok & Renk değişikliği yok \\
\hline \multirow{5}{*}{$\begin{array}{l}\text { Erken } \\
\text { ayrışma } \\
\text { II. Dönem }\end{array}$} & $2 P$ & 1 & $\begin{array}{l}\text { Pembe-beyaz renk } \\
\text { Epidermal sıyrılma, saç } \\
\text { kaybı }\end{array}$ & $\begin{array}{l}\text { Pembe-beyaz renk } \\
\text { Epidermal sıyrılma, } \\
\text { mermerleşme }\end{array}$ & $\begin{array}{l}\text { Pembe-beyaz renk } \\
\text { Kol ve bacakta epidermal } \\
\text { siyrılma }\end{array}$ \\
\hline & $3 P$ & 2 & Gri - yeşil renk & Gri - yeşil renk & Gri-yeşil renk, mermerleşme \\
\hline & $4 P$ & 3 & $\begin{array}{l}\text { Renk solması, } \\
\text { kahverengi tonlar, } \\
\text { burun, kulak, dudaklarda } \\
\text { kuruma }\end{array}$ & $\begin{array}{l}\text { Batında şişme, global } \\
\text { koyu yeşil renk, çürüme } \\
\text { sıvılarının çıkışı }\end{array}$ & $\begin{array}{l}\text { Kahverengi tonlar,el - } \\
\text { ayak parmaklarında/ uzuv } \\
\text { çıkıntılarında kuruma }\end{array}$ \\
\hline & $5 P$ & 4 & $\begin{array}{l}\text { Ağı, göz, kulak, } \\
\text { burundan çürüme } \\
\text { sıvilarının ç1kışı, yüz- } \\
\text { boyunda şişme }\end{array}$ & $\begin{array}{l}\text { Gövdede yeşil-siyah renk } \\
\text { değişimi }\end{array}$ & $\begin{array}{l}\text { Kahverengi- siyah renk } \\
\text { değişimi, derinin sıvı kaybı } \\
\text { ile kuruması }\end{array}$ \\
\hline & $6 P$ & 5 & $\begin{array}{l}\text { Kahverengi-siyah renk } \\
\text { değişimi }\end{array}$ & - & - \\
\hline \multirow{3}{*}{$\begin{array}{l}\text { İleri derecede } \\
\text { ayrışma }\end{array}$} & $7 P$ & 1 & $\begin{array}{l}\text { Göz ve boyun } \\
\text { bölgesinde çökme } \\
\text { görünümü }\end{array}$ & Karın bölgesinin çökmesi & $\begin{array}{l}\text { Kemik-yumuşak doku } \\
\text { arasında nemli ayrışma } \\
\text { (iskeletleşme }<\% \text { 0) }\end{array}$ \\
\hline & $8 P$ & 2 & $\begin{array}{l}\text { Kemik-yumuşak doku } \\
\text { arasında nemli ayrışma } \\
\text { (iskeletleşme }<\% \text { ) }\end{array}$ & $\begin{array}{l}\text { Kemik-yumuşak doku } \\
\text { arasında nemli ayrışma } \\
\text { (iskeletleşme }<\% \text { ) }\end{array}$ & Mumyalaşma başlangıcı \\
\hline & 9P & 3 & Mumyalaşma başlangıcı & Mumyalaşma başlangıcı & - \\
\hline \multirow{4}{*}{ İskeletleşme } & $10 \mathrm{P}$ & 1 & $\begin{array}{l}\text { İskeletleşme }>\% 50 \\
\text { Kemik yüzeyi yağlı- } \\
\text { çürümüş doku ile kaplı }\end{array}$ & $\begin{array}{l}\text { Gövdede iskeletleşme } \\
\text { başlangıcı } \\
\text { Kemik yağlı çürümüş } \\
\text { doku ile kaplı olabilir }\end{array}$ & $\begin{array}{l}\text { İskeletleşme }>\% 50 \\
\text { Kemik yüzeyi yağlı çürümüş̧ } \\
\text { doku ile kaplıdır }\end{array}$ \\
\hline & $11 P$ & 2 & $\begin{array}{l}\text { İskeletleşme }>\% 50 \\
\text { Kemik yüzeyi kuru ve } \\
\text { mumyalaşmış doku ile } \\
\text { kaplıdır }\end{array}$ & $\begin{array}{l}\text { İskeletleşme ve az oranda } \\
\text { kurumuş doku ile kaplı }\end{array}$ & Tama yakın iskeletleşme \\
\hline & $12 P$ & 3 & Tama yakın iskeletleşme & Tama yakın iskeletleşme & Tam iskeletleşme \\
\hline & $13 \mathbf{P}$ & 4 & Tam iskeletleşme & Tam iskeletleşme & - \\
\hline
\end{tabular}

\footnotetext{
* Megyesi ve ark. 2005 çalışmasından uyarlanmıştır.
} 
(47). Tamamen iskeletleşmesi değil kimyasal yağ çökeltilerine bakıldığı için ıslaklığın kurumasıdır. Megyesi (41) için ise iskeletleşme skorunun başlangıcı $1285^{\prime}$ dir. Örneğin; bir cesettin 100 ADD'ye ulaşması için; $20^{\circ} \mathrm{C}$ sicaklıkta 5 gün, $25^{\circ} \mathrm{C}$ sicaklıkta 4 gün, $10^{\circ} \mathrm{C}$ sicaklıkta ise 10 gün geçirmesi gerekir.

ADD ve vücut ağırlığını ayarlamak için geliştirilmiş olan tabloya bakarak formüle uyarlanır (47). Bu tablonun geliştirilmesinin sebebi farklı ağırlıkta deneklerin kullanılmasından dolayıdır. Tabloda kiloya göre düzeltme faktörleri bulunur ve 1285 ile çarpılır (Tablo 2). Bu tabloda ağırlık birimi olarak lbs kullanıldığından kilogramın lbs çevrilmesi ve karşılığına bakılması gerekir. Örneğin $23 \mathrm{~kg}$ ağırlığında bir deneğin lbs ağırlığı 0-49 aralığına girer. Bu aralığın da düzeltme faktörü 0,1667'dir. 1285 ADD ile düzeltme faktörün çarpımından da $23 \mathrm{~kg}$ ağırlığındaki hayvanın iskeletleşme ADD'sine ulaşılır.

Tablo 2. Kiloya göre düzeltme faktörleri*

\begin{tabular}{|l|l|l|}
\hline Aralık & Artma miktarı (lbs) & Standart \\
\hline \multirow{5}{*}{50} & $0-49$ & 0,1667 \\
\cline { 2 - 3 } & $50-99$ & 0,5000 \\
\cline { 2 - 3 } & $100-149$ & 0,8333 \\
\cline { 2 - 3 } & $150-199$ & 1,1677 \\
\cline { 2 - 3 } & $200-249$ & 1,5000 \\
\cline { 2 - 3 } & $250-300$ & 1,8333 \\
\hline \multirow{3}{*}{100} & $0-99$ & 0,3333 \\
\cline { 2 - 3 } & $100-199$ & 1,0000 \\
\cline { 2 - 3 } & $200-299$ & 1,6667 \\
\hline \multirow{3}{*}{150} & $0-149$ & 0,5000 \\
\cline { 2 - 3 } & $150-299$ & 1,5000 \\
\hline
\end{tabular}

*Ağırlık standartları 50, 100 ve 150 lbs ağırlık artışlarına dayanmaktadır. Vass ve ark. 1992, çalışmasından uyarlanmıştır.

$$
1285 \mathrm{ADD} * 0,1667=214,2 \mathrm{ADD}
$$

$23 \mathrm{~kg}$ ağırlığındaki karkas iskeletleşme ADD 214,2'dir. Yani $23 \mathrm{~kg}$ ağırlığındaki bir deneğin iskeletleşmesi için 214,2 $\mathrm{C}^{\mathrm{o}}$ biriktirmesi gerekir. Günlük ortalama sicaklığın $15,4 \mathrm{C}^{\circ}$ olduğu varsayılırsa;

214,2 ADD / 15,4 = 13,9 gün bulunur.

Sonuçta $23 \mathrm{~kg}$ ağırlıkta bir deneğin günlük ortalama sıcaklığ $15,4 \mathrm{C}^{\circ}$ olduğu varsayılırsa 13,9 günde yani 14 günde iskeletleşme aşamasına ulaşır. Ulaşılan bu iskeletleşme aşaması deneğin tamamen iskeletleşmesi değil kimyasal yağ çökeltilerine bakıldığında islaklığın ku- ruması ve cesedin lokal bir bölgesinde iskeletleşmenin başlamasıdır (41). Bu denek için iskeletleşme skorunun başlangıcı 214,2'dir. Örneğin, sıcaklık ortalaması 28,7 C olsaydı iskeletleşme süresi 7,5 gün olacaktır.

Ölüm sonrası geçen zaman aralığını bulmak için ilk adım olarak ADD bulunması gerekir. ADD hesaplamak için TBS ile kullanılan formül Galloway (50) tarafindan bulunmuş Megyesi (41) tarafından geliştirilmiştir. ADD hesaplamak için TBS tespiti gereklidir. Denklem şudur;

$$
\mathrm{ADD}=0,002(\mathrm{TBSTBS})+1,81 \pm 388,16
$$

ya da daha basitleştirilmiş hali ile;

$$
\mathrm{ADD}=10^{(0,002 * \mathrm{TBS} * \mathrm{TBS}+1,81)} \pm 388,16
$$

Örnek bir TBS (TBS = 28) puanlaması ile ADD hesaplamasını yapmak gerekirse;

$$
\begin{aligned}
& \mathrm{ADD}=10^{\left(0,002 * 28^{* 28+1,81)} \pm 388,16\right.} \\
& \mathrm{ADD}=10^{(3,378)} \pm 388,16 \\
& \mathrm{ADD}=2387,81 \pm 388,16
\end{aligned}
$$

Bireyin ölüm tarihinden itibaren geçen süre 1999,65 ADD ile 2775,97 ADD aralığındadır. Yerel hava istasyonlarından geriye dönük olarak günlük ortalama s1caklık alınır. Ölüm sonrası zamanı bulmak için en yakın olan hava istasyonundan elde edilecek ortalama sicaklık verileri geriye doğru 2387,81 ADD ulaşıncaya kadar toplanır. Verilerden $0^{\circ} \mathrm{C}$ altında olan sıcaklık değerleri için sıfır değeri verilir. Nedeni donma noktasının altında çürümenin/ayrışmanın gerçekleşmemesidir. Bu nedenle ADD toplanırken eksi değerler için sıfır verilerek toplanır. Formülde sıcaklık birimi olarak fahrenhayt ( $f a h$ renheit) kullanıldığından dolayı santigrat olan sıcaklık değerlerin fahrenhayta çevrilmesi gerekir. Aşağıdaki formül kullanılır;

$$
\mathrm{F}^{\circ}=\mathrm{C}^{\circ} \times 1.8+32
$$

Günlük sıcaklık ortalamasının 29,4 Co olduğu varsay1lırsa bunun fahrenhayt değeri $85 \mathrm{~F}^{\circ}$ bulunur. Örnek diş1 kullanımda günlük sıcaklık ortalamaları en yakın hava istasyonundan temin edilir. Sonrasında bulunan ADD'yi buluncaya kadar geriye dönük olarak sıcaklık toplanır.

Ölümden sonra geçen zaman aralığı 1999,65 ADD ile 2775,97 ADD olan bir cesedin gün bazında aralığı bulunan ADD'ler sıcaklığa bölünür;

$$
\frac{1999,65}{85}=23,5 \text { ile } \frac{2775,97}{85}=32,6 \text { çıkar. }
$$


Bazen mevsimsel soğuk dönemlerin olduğu bölgelerde çürümenin ve ayrışmanın yavaşlamasından dolayı ölüm zamanı aralığını tahminde \% 95 oranında güven aralığı içeren aşağıdaki formül kullanılır (41);

$$
2387,81 \pm 776,32 * \sqrt{1,02+\frac{(T B S-17,2)^{2}}{3522,42}}
$$

TBS 28 puanlaması için;

$$
\mathrm{ADD}=2387,81 \pm 776,32 * \sqrt{1,02+\frac{(28-17,2)^{2}}{3522,42}}
$$

$\mathrm{ADD}=2387,81$

$\mathrm{ADD}=2387,81796,67$

$\mathrm{ADD}=1591,14$ ile 3184,48 aralığında çıkar

Bulunan sonuçlar itibari ile aralığın 24 gün ile 33 gün arasında olduğu bulunur. Olay yerinde bulunan cesedin ölümünden sonra geçen zaman aralığı 24 gün ile 33 gün arasında olduğu sonucuna ulaşıllır.

\section{Tartışma}

Birçok yöntemle PMİ tahmini yapılmaya çalışıldığı ancak özellikle; biyokimyasal, mide boşalması, elektrofizyolojik, adli patolojik, flow-sitometrik ve mikrobiyolojik incelemeler gibi erken PMİ tahmininde kullanılan yöntemler hücrelerin dizisi, hücresel pompaların çalışmaması, pütrefaksiyonla birlikte üretilen organik ve inorganik maddelerin interferansı gibi birçok çeşitli faktörler nedeniyle sonuca ulaşma noktasında yeterli olmamaktadır. PMİ tespitinde kullanılan patolojik yöntemler ölümden sonraki ilk bir kaç saatlik sürede güvenilir sonuçlar vermekte, ancak özellikle 72 saatten sonra kullanılamamaktadır $(26,64)$. Diğer yandan özellikle ayrışma süreci belirginleşmiş cesetlerde PMI tahmininde bu yöntemlerin anlamı bulunmamaktadır. $\mathrm{Bu}$ noktada, yukarıda sözü edilen yöntemlerin aksine, cesetteki postmortem değişimleri ve bu değişimlerin zaman-interferan faktörlerle ilişkisini ortaya koyan önemli bilimsel metodoloji olan adli tafonomi devreye girmektedir.

Çürümenin erken dönemlerinde vücuttaki flora bakterilerinin temel etkenlerden biri olduğu bilinmektedir. Dolayısıyla flora bakterilerini etkileyen durumlar çürüme evrelerini de etkileyebilmektedir. Antemortem dönemde flora bakterilerini etkileyen durumlar, flora bakterilerinin niteliği, gastrointestinal ülserasyon varlığı, barsak perforasyonu ile seyreden ölüm nedenleri gibi birçok sebep çürümenin ilk evresinde farkl1l1klara neden olabilmektedir. Cesedin gömülü ya da açıkta olması, cesedin bulunduğu ortamdaki nem, toprak özellikleri, çevre florası ve faunası, sıcaklık ve hava hareketleri de çürümenin tüm evrelerinde çürüme hızına etki eden faktörler olarak karşımıza çıkmakta ve çürüme evreleri ile PMİ tayini arasındaki bağlantıyı güçleştirmektedir $(2,7)$.
Ülkemizde PMİ konusunda bölgesel standartlar ortaya konulmamıştır. Çevresel faktörler ölümden sonraki süreçte vücuttaki yumuşak dokunun ayrışmasını etkiler. Tafonomik süreçteki ve çürüme aşamasındaki ayrışmay1 ve bölgesel olarak farklılıkları ortaya koyan araştırma bulunmamaktadır. Bölgelere özgü farklılıkların ve standartların belirlenmesi ile PMİ tahminlerinin doğruluğu ve bilimseliği artırılmış olacak, bununla birlikte kullanılan yöntemin uygulanabilir ve tekrarlanabilir olmasını sağlayacaktır.

Amerika, Avusturalya, Afrika ve Avrupa kıta ülkelerinde PMİ konusunda karkas ve insan denekleri üzerinde yapılmış çalışmalar mevcut olmakla birlikte yeni çalışmalar da yürütülmektedir. Henüz ülkemiz şartlarında yapılmış bir çalışma bulunmamaktadır.

Dekompozisyon süreci ve PMİ tahminine yönelik veriler ilk zamanlar daha çok Amerika Birleşik Devletleri Hawaii ve Tennessee eyaletlerindeki vaka çalışmalarından ve deneysel araştırmalardan elde edilmekteydi. Günümüzde Tennessee Üniversitesi olmak üzere Western Carolina Üniversitesi, Texas State Üniversitesi, Sam Houston State Üniversitesi ve Southern Illinois Üniversitesi içinde tahsis edilen araştırma sahalarında dekompozisyon süreci ve PMİ konusunda çalışmalar yürütülmektedir (27,47,56,58,59,65-68). Kuzey Amerika'da birikmiş gün sicaklıkları PMI'nin belirlenmesinde kullanılırken $(41,47,58,69,70)$ Megyesi'nin geliştirmiş olduğu yöntem ise Montana, Iowa ve Indiana eyaletlerinde kullanılmış ve başarılı bir şekilde uygulanmıştır $(69,70)$.

Kuzey Afrika'da Megyesi metodu PMİ tahmininde uygulanmıştır (71). Son yıllarda ise deneysel araştırmalarda İngiltereli bilim insanlarının da yer aldığı görülmektedir $(49,62,72)$. Kuzey İngiltere'de Megyesi tarafindan geliştirilen yöntem bölgesel özellikler göz önünde bulundurulmadan test edilmiştir. Çalışmada, farklı mevsimlerde ölmüş ve toprak üzeri açık ortamdaki kemirici etkisi olmayan vakalar içerisinde, aynı bölgeden farklı yerlerden 20 gerçek adli vaka seçilmiştir. Çalışma neticesinde 20 vakadan 12 'sinde, PMİ tahmini doğru çıkmış, diğer 8 vakada ise bölgesel faktörler bilinmediğinden dolayı PMI aralığına yakın sonuçlar elde edilmiştir (73).

Avusturalya ve Brezilya'da PMİ ve dekompozisyon hakkında çalışmalar yürütülmektedir $(21,74,75)$. Kanada'da ADD'ye dayalı Megyesi yöntemi birçok durumda etkili ve uygulaması kolay bulunmuş ve adli bağlamda tüm vakalara uygulanması için bölgesel farklılıkların tespit edilerek bölgesel olarak uyarlanması gerektiği savunulmuştur $(68,76)$.

Ancak ülkemizde daha önceden kapsamlı bir deneysel adli tafonomik çalışma bulunmadığından cesetlerin postmortem ayrışma süreci ile coğrafi ve iklimsel özel- 
likler arasındaki ilişki bilinmemektedir. Bu bağlamda, ölüm zamanı tayini konusunda ülkemiz iklim şartlarında deneysel olarak araştırma yaparak tafonomik sürecin nasıl işlediğinin ve dekompozisyonu etkileyen bölgesel faktörlerin belirlenmesi gerekmektedir.

\section{Sonuç}

Postmortem interval tahmininde ayrışma sürecine etki eden bölgesel iklim farklılıkları ile tafonomik yorumlama ülkeden ülkeye hatta aynı ülkede bölgeden bölgeye değişiklik göstermektedir. Bununla birlikte, yürütülecek olan deneysel çalı̧̧malar ile bölgesel dekompozisyon süreci belirlenmesi ve geliştirilen formül ile tahmin edilecek ölüm zamanı konusunun ülkemiz iklim şartlarında uygulanabilirliğinin ortaya konması gerekmektedir. Böylece daha bilimsel ve daha doğru PMİye ulaşma imkânı mümkün olabilecektir.

\section{Kaynaklar}

1. Dolinak D, Matshes E, Lew EO. Forensic Pathology: Principles and Practice. Burlington: Academic Press; 2005.

2. Saukko P, Knight B. Knightss Forensic Pathology. 3rd Ed. Arnold, London: CRC Press, 2004.

3. DiMaio D, VJ D. Forensic Pathology. Boca Raton: CRC Press, 2001.

4. McLay WDS. Clinical Forensic Medicine. Cambrigde: Cambridge University Press, 2009.

5. Madea B, Tsokos M, Preuß J. Death Due to Hypothermia Morphological Findings, Their Pathogenesis and Diagnostic Value. Forensic Pathology Reviews: Springer. 2008:3-21.

6. Madea B, Käferstein H, Hermann N, Sticht G. Hypoxanthine in Vitreous Humor and Cerebrospinal Fluid $\neg$-A Marker of Postmortem Interval and Prolonged (Vital) Hypoxia? Remarks Also on Hypoxanthine in SIDS. Forensic Sci Int 1994;65(1):19-31.

7. Koç S. Ölüm Zamanı ve Postmortem Interval Belirlenmesi. İstanbul Üniversitesi Cerrahpaşa Tıp Fakültesi Adli Tıp Ders Kitabı 1. Cerrahpaşa Tıp Fakültesi Yayınları, 2011, İstanbul.

8. Kaliszan M, Hauser R, Kernbach-Wighton G. Estimation of the Time of Death Based on the Assessment of Post Mortem Processes with Emphasis on Body Cooling. Legal Med 2009;11(3):111-7.doi: 10.1016/j.legalmed.2008.12.002.

9. Mall G, Eisenmenger W. Estimation of Time Since Death by Heat-Flow Finite-Element Model. Part I: Method, Model, Calibration and Validation. Legal Med 2005;7(1):1-14.

10. Mall G, Eisenmenger W. Estimation of Time Since Death by Heat-Flow Finite-Element Model Part II: Application to Non-Standard Cooling Conditions and Preliminary Results in Practical Casework. Legal Med 2005;7(2):69-80.

11. Coe JI. Postmortem Chemistry Update Emphasis on Forensic Application. Am J Forensic Med Pathol 1993;14(2):91-117.

12. Quan L, Zhu BL, Ishikawa T, Michiue T, Zhao D, Li DR, Ogawa M, Maeda H. Postmortem Serum Erythropoietin Levels in Establishing the Cause of Death and Survival Time at Medicolegal Autopsy. Int J Legal Med 2008;122(6):481-
7.

13. Jashnani KD, Kale SA, Rupani AB. Vitreous Humor: Biochemical Constituents in Estimation of Postmortem Interval. J Forensic Sci 2010;55(6):1523-7. doi: 10.1111/j.1556-4029.2010.01501.x.

14. Munoz JI, Suarez-Penaranda JM, Otero XL, RodriguezCalvo MS, Costas E, Miguens X, Concheiro L. A New Perspective in The Estimation of Postmortem Interval (PMI) Based on Vitreous. J Forensic Sci 2001;46(2):209-14.

15. Quan L, Ishikawa T, Hara J, Michiue T, Chen J-H, Wang Q, Zhu BL, Maeda H. Postmortem Serotonin Levels in Cerebrospinal and Pericardial Fluids With Regard to the Cause of Death in Medicolegal Autopsy. Legal Med 2011;13(2):75-8. doi: 10.1016/j.legalmed.2010.11.003.

16. Hejna P, Zátopková L, Tsokos M. The Diagnostic Value of Synovial Membrane Hemorrhage and Bloody Discoloration of Synovial Fluid ("Inner Knee Sign") in Autopsy Cases of Fatal Hypothermia. Int J Legal Med 2012;126(3):415-9.

17. Querido D. Time-Dependent Changes in Electrical Resistance of the Intact Abdomen During the 1-504 H Postmortem Period in Rats. Forensic Sci Int 1994;67(1):1725.

18. Elmas I, Baslo MB, Ertas M, Kaya M. Compound Muscle Action Potential Analysis in Different Death Models: Significance for The Estimation of Early Postmortem Interval. Forensic Sci Int 2002;127(1):75-81.

19. Di Nunno N, Costantinides F, Cina SJ, Rizzardi C, Di Nunno C, Melato M. What Is The Best Sample for Determining The Early Postmortem Period By on-The-Spot Flow Cytometry Analysis? Am J Forensic Med Pathol 2002;23(2):173-80.

20. Mathur A, Agrawal Y. An Overview of Methods Used for Estimation of Time Since Death. Australian J Forensic Sci 2011;43(4):275-85.

21. Morris J, Harrison L, Partridge S. Postmortem Bacteriology: A Re-Evaluation. J Clinical Pathol 2006;59(1):1-9. doi: 10.1136/jcp.2005.028183.

22. Saegeman V, Verhaegen J, Lismont D, Verduyckt B, De Rijdt T, Ectors N. Influence of Postmortem Time on the Outcome of Blood Cultures Among Cadaveric Tissue Donors. European J Clinical Microbiol \& Infectious Diseases 2009;28(2):161-8.

23. Morris JA, Harrison LM, Biswas J, Telford DR. Transient bacteraemia: a possible cause of sudden life threatening events. Medical Hypotheses 2007;69(5):1032-9. doi: 10.1016/j.mehy.2007.02.039.

24. Catts E. Problems in Estimating the Postmortem Interval in Death Investigations. J Agricultural Entomology 1992;9(4):245-55.

25. VanLaerhoven S, Anderson G. Forensic Entomology Determining Time of Death in Buried Homicide Victims Using Insect Succession, Technical Report TR-02 96. Ottawa, Ontario: Canadian Police Research Centre, 1996.

26. Goff M, Flynn M. Determination of Postmortem Interval by Arthropod Succession: A Case Study from the Hawaiian Islands. J Forensic Sci 1991;36(2):607-14.

27. Goff M. Estimation of Postmortem Interval Using Arthropod Development and Successional Patterns. Forensic Sci Review 1993;5(2):81-94.

28. Karapazarlığlu E. Doğal Ortamda Domuz Karkasları Üzerine Gelen Arthropoda>ların ve Süksesyonlarının 
Belirlenmesi. Ondokuz Mayıs Üniversitesi Fen Bilimleri Enstitüsü, Yüksek Lisans Tezi. Samsun-2004.

29. Şabanoğlu B. Ankara İlinde (Merkez İlçe) Leş Üzerindeki Calliphoridae (Diptera) Faunasının Belirlenmesi ve Morfolojilerinin Sistematik Yönden İncelenmesi. Hacettepe Üniversitesi Fen Bilimleri Enstitüsü, Yüksek Lisans Tezi. Ankara-2007.

30. Özdemir S. Ankara İli’nde (Merkez İlçe) Leş Üzerindeki Coleoptera Faunasının Belirlenmesi ve Morfolojilerinin Sistematik Yönden İncelenmesi. Hacettepe Üniversitesi Fen Bilimleri Enstitüsü, Yüksek Lisans Tezi. Ankara-2007.

31. Yuca P. İstanbul Pendik İlçesi Akfırat Beldesi`nde Adli Entomolojìde Kullanılan Sinek Türlerinin Belirlenmesi. İstanbul Üniversitesi Adli Tip Enstitüsü Fen Bilimleri Anabilim Dalı, Yüksek Lisans Tezi. İstanbul-2009.

32. Bana R. Edirne İli Trakya Üniversitesi Güllapoğlu (Balkan) Yerleşkesi'nde Adli Entomoloji Yönünde Önem Taşıyan Coleoptera Faunasının Leş Üzerinden Toplanması ve Taksonomik Yönden İncelenmesi. Trakya Üniversitesi Fen Bilimleri Enstitüsü, Yüksek Lisans Tezi. Edirne-2010.

33. Karapazarlığlu E. Kapalı Ortamda Domuz Karkasları Üzerine Gelen Böcek Türlerinin ve Süksesyonlarının Belirlenmesi ve Bir Örnek Vaka Çalışması. Ondokuz Mayıs Üniversitesi Fen Bilimleri Enstitüsü, Doktora Tezi. Samsun-2010.

34. Karapazarlıŏglu E. Samsun Bölgesinde Meydan Gelen Bir Cinayet Olayında, Olay Yerinin Medikokriminal Adli Entomoloji Açısından İncelenmesi. Türkiye 1 Bitki Koruma Kongresi; Samsun-2004.

35. Dogan KH, Gunaydin G, Demirci S, Koc S. Postmortem Changes in Element Levels in Rat Skeletal Muscle Tissue. Turkiye Klinikleri Journal of Medical Sciences 2010;30(4):1332-1338.

36. Dokgöz H, Arican N, Elmas I, Fincanci SK. Comparison of Morphological Changes in White Blood Cells After Death and in Vitro Storage of Blood for the Estimation of Postmortem Interval. Forensic Sci Int 2001;124(1):25-31

37. Kurtulus A, Acar K, Sorkun H, Kelten C, Boz B. The Relationship between Adrenal Gland Morphometric Changes and Postmortem Intervalin Rats: A Stereological Study. Legal Med (Tokyo). 2012;14(4):214-218.

38. Smith KG. A Manual of Forensic Entomology. Ithaca, NY: Cornell University Press, 1986.

39. Haglund WD, Sorg MH. Method and Theory of Forensic Taphonomy Research. In: Haglund WD, Sorg MH, editors. Forensic Taphonomy: The Postmortem Fate of Human Remains. Boca Raton FL: CRC Press, 1997:13-25.

40. Bass WM. Outdoor Decomposition Rates in Tennessee. In: Haglund WD, Sorg MH, editors. Forensic Taphonomy: The Postmortem Fate of Human Remains. Boca Raton: CRC Press, 1997:181-6.

41. Megyesi MS, Nawrocki SP, Haskell NH. Using Accumulated Degree-Days to Estimate the Postmortem Interval from Decomposed Human Remains. J Forensic Sci 2005;50(3):618-26.

42. Michaud JP, Moreau G. A Statistical Approach Based on Accumulated Degree days to Predict Decomposition Related Processes in Forensic Studies. J Forensic Sci 2011;56(1):22932. doi: 10.1111/j.1556-4029.2010.01559.x.

43. Efremov IA. Taphonomy: A New Branch of Paleontology. Pan-American Geologist 1940;74(2):81-93.
44. Haglund WD, Reay D, Swindler D. Canid Scavenging/ Disarticulation Sequence of Human Remains in The Pacific Northwest. J Forensic Sci 1989;34(3):587-606.

45. Dirkmaat DC, Adovasio JM. The Role of Archaeology in the Recovery and Interpretation of Human Remains From an Outdoor Forensic Setting. In: Haglund WD, Sorg MH, editors. Forensic Taphonomy: The Postmortem Fate of Human Remains. Boca Raton: CRC Press,1997:39-64.

46. Beary MO, Lyman RL. The Use of Taphonomy in Forensic Anthropology: Past Trends and Future Prospects. In:Dirkmaat DC, editor. A Companion to Forensic Anthropology. Malden, MA: Wiley-Blackwell, 2012:499-527.

47. Vass AA, Bass WM, Wolt JD, Foss JE, Ammons JT. Time Since Death Determinations of Human Cadavers Using Soil Solution. J Forensic Sci 1992;37(5):1236-53.

48. Mann RW, Bass WM, Meadows L. Time Since Death and Decomposition of the Human Body: Variables and Observations in Case and Experimental Field Studies. J Forensic Sci 1990;35(1):103-11.

49. Adlam RE, Simmons T. The Effect of Repeated Physical Disturbance on Soft Tissue DecompositionAre Taphonomic Studies an Accurate Reflection of Decomposition?. J Forensic Sci 2007;52(5):1007-14. doi: 10.1111/j.1556-4029.2007.00510.x.

50. Galloway A. The Process of Decomposition: A Model from The Arizona-Sonoran Desert. In: Haglund WD, Sorg MH, editors. Forensic Taphonomy: The Postmortem Fate of Human Remains. Boca Raton: CRC Press, 1997:139-50.

51. Christensen AM, Passalacqua NV, Bartelink EJ. Forensic Anthropology: Current Methods and Practice: Elsevier: 2013.

52. Ubelaker DH. Postmortem Internal. In: A SJ, S SP, editors. Encyclopedia of Forensic Sciences. Second ed. Waltham: Academic Press, 2013.

53. MacGregor DM. Decomposition of Pig Carrion in Southeast Queensland, Australia, During Winter. Paper presented at 51 st American Academy of Forensic Sciences Annual Meeting; Orlando, FL-1999.

54. Hobischak NR. Freshwater Invertebrate Succession and Decompositional Studles on Carrion in British Columbia. Simon Fraser University, Master Thesis. Ottawa, Canada-1997.

55. MacDonell N, Anderson G. Aquatic Forensics: Determination of Time Since Submergence Using Aquatic Invertebrates. Burbany: Canadian Police Research Centre, 1997.

56. Rodriguez WC. Decomposition of Buried and Submerged Bodies. In: Haglund WD, Sorg MH, editors. Forensic Taphonomy: The Postmortem Fate of Human Remains Boca Raton, USA: CRC Press, 1997:459-68.

57. Nawrocki SP, E LK. Modeling core and peripheral processes in human decomposition: A conceptual framework. Proceedings of the 65th annual meeting of the American Academy of Forensic Sciences; February 18-23; Washington, DC 2013.

58. Vass AA. The Elusive Universal Post-Mortem Interval Formula. Forensic Sci Int 2011;204(1):34-40. doi: 10.1016/j.forsciint.2010.04.052.

59. Micozzi MS. Frozen Environments and Soft Tissue Preservation. In: Haglund WD, Sorg MH, editors. Forensic Taphonomy, the Postmortem Fate of Human Remains 200. 
Boca Raton, Florida: CRC Press, 1997:171-80.

60. Clark MA, Worrell MB, Pless JE. Postmortem Changes in Soft Tissues. In: Haglund WD, Sorg MH, editors. Forensic Taphonomy: The Postmortem Fate of Human Remains. Boca Raton: CRC Press, 1997:151-64.

61. Buchan M, Anderson G. Time Since Death: A Review of the Current Status of Methods Used in the Later Postmortem Interval. Canadian Society Forensic Sci J 2001;34(1):1-22.

62. Simmons T, Cross P. Forensic Taphonomy. In: A SJ, S SP, editors. Encyclopedia of Forensic Sciences. Second ed. Walthaw: Academic Press, 2012:12.

63. Marks M, Love J, Dadour I. Taphonomy and Time: Estimating the Postmortem Interval. Hard Evidence: Case Studies in Forensic Anthropology, 2nd edn Upper Saddle River, NJ: Prentice Hall, 2009:165-78.

64. Coe JI, Curran WJ. Definition and Time Of Death. In: Curran WJ, McGarry AL, S PC, editors. Modern Legal Psychiatry and Forensic Science. Philadelphia: FA Davis Co, 1980:1310.

65. Schroeder H, Klotzbach H, Oesterhelweg L, Püschel K. Larder Beetles (Coleoptera, Dermestidae) as An Accelerating Factor for Decomposition of A Human Corpse. Forensic Sci Int 2002;127(3):231-6.

66. Steadman DW, Adams BJ, Konigsberg LW. Statistical Basis for Positive Identification in Forensic Anthropology. Am J Physical Anthropol 2006;131(1):15-26. doi: 10.1002/ ajpa.20393.

67. Pope MA. Differential decomposition Patterns of Human Remains in Variable Envirmonts of the Midwest. University of South Florida, Masters Thesis. Florida, USA-2010.

68. Larizza M. Physical and Chemical Analysis of Pig Carcass Decomposition in A Fine Sand. University of
Ontario Institute of Technology, Masters Thesis. Oshawa, Canada-2010.

69. Parsons HR. The Postmortem Interval: A Systematic Study of Pig Decomposition in West Central Montana. The University of Montana, Masters Thesis. USA-2009.

70. Schiel M. Using Accumulated Degree Days for Estimating the Postmortem Interval: A Re-evaluation of Megyesi's Regression Formulae. University of Indianapolis, Masters Thesis. Indiana, USA-2008.

71. Myburgh J, L'Abbé EN, Steyn M, Becker PJ. Estimating the Postmortem Interval (PMI) Using Accumulated Degree Days (ADD) in A Temperate Region of South Africa. Forensic Sci Int 2013;229(1):165-el.

72. Simmons T, Adlam RE, Moffatt C. Debugging Decomposition Data-Comparative Taphonomic Studies and the Influence of Insects and Carcass Size on Decomposition Rate. J Forensic Sci 2010;55(1):8-13. doi: 10.1111/j.15564029.2009.01206.x.

73. Sorg MH. Developing Regional Taphonomic Standards. Report (Study/Research). USA: National Institute of Justice, 2013.

74. Fitzgerald CM, Oxenham M. Modelling Time-Since-Death in Australian Temperate Conditions. Australian J Forensic Sci 2009;41(1):27-41.

75. Oliveira-Costa J, de Mello-Patiu CA. Application of Forensic Entomology to Estimate of the Postmortem Interval (PMI) in Homicide Investigations by the Rio De Janeiro Police Department in Brazil. Anil Aggrawal's Int J Forensic Med Toxicol 2004;234(3978):165.75. 5 40-44.

76. Dautartas AM. The Effect of Various Coverings on The Rate of Human Decomposition.The University of Tennessee, Masters Thesis. Knoxville, USA-2009. 